\title{
LLIF IN THE CORRECTION OF DEGENERATIVE SCOLIOSIS IN ELDERLY PATIENTS
}

\section{LLIF NA CORREÇÃO DA ESCOLIOSE DEGENERATIVA EM PACIENTES IDOSOS \\ LLIF EN LA CORRECCIÓN DE LA ESCOLIOSIS DEGENERATIVA EN PACIENTES DE LA TERCERA EDAD}

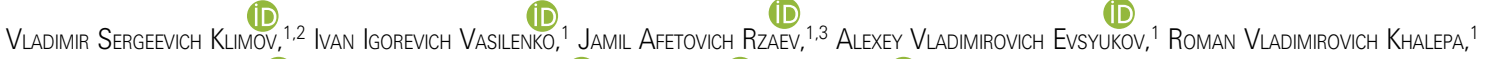 \\ Evgeniya Valeryevna Amelina, ${ }^{3}$ Sergey Olegovych Ryabykh, ${ }^{4}$ Priyank Sinha, Marcel Ivanov ${ }^{5}$ \\ 1. Federal Neurosurgical Center, Department of Neurosurgery, Novosibirsk, Russia. \\ 2. Novosibirsk State Medical University, Novosibirsk, Russia. \\ 3. Novosibirsk State University, Novosibirsk, Russia. \\ 4. llizarov Center, Department of Orthopaedic Spine Surgery, Division of Spine Pathology and Rare Diseases, Kurgan, Russia. \\ 5. Royal Hallamshire Hospital, Department of Neurosurgery, Sheffield, UK.
}

\begin{abstract}
Objective: The incidence of adult degenerative scoliosis (ADS) among individuals over 50 years old can be as high as $68 \%$. Surgical interventions aimed at correcting the spinal deformity in elderly patients are accompanied by a high risk of complications. The use of lateral lumbar interbody fusion (LLIF) is associated with lower rates of complications when compared with open anterior or posterior fusions. Methods: Ninety-three patients with ADS (23 men, 70 women) were operated at the Federal Neurosurgical Center. The average age was 63 (52 to 73 years). Results: Back pain, measured according to the Visual Analogue Scale (VAS), decreased from 5.9/6 (4;8) (format - mean/ median $(1 ; 3$ quartile) ) to $2.6 / 3(1 ; 3)$ points $(p<0.0001)$. Leg pain according to the VAS decreased from $4.6 / 4(3 ; 7)$ to $1.4 / 1(0 ; 2)$ points $(p$ $<0.0001$ ). Functional adaptation according to the Oswestry Disability Index (ODI) improved from $47.8 \pm 17.4$ to $38.5 \pm 14.5$ ( $p<0.0273$ ). Pelvic tilt (PT) before the surgery was $23.9 \pm 12.2^{\circ}$ whereas at 12 months follow-up it was $16.8 \pm 5.9^{\circ}(p<0.0001)$. Pl-LL mismatch pre surgery was $12.1 / 13(9 ; 16)^{\circ}$ whereas 12 months later it was $7.9 / 8(6 ; 10)^{\circ}(p=0.0002)$. Conclusions: Restoration of local sagittal balance in ADS patients by short-segment fixation using LLIF technology leads to a statistically significant improvement in quality of life and increased functional adaptation. A lower incidence of early and late postoperative complications, less intraoperative blood loss and shorter hospital stay makes LLIF, in combination with minimally invasive transpedicular fixation, the method of choice to correct ADS in elderly patients. Level of evidence IV; Case series.
\end{abstract}

Keywords: Adult; Scoliosis; Spine; Deformity; Quality of Life.

\section{RESUMO}

Objetivo: A incidência de escoliose degenerativa do adulto (EDA) entre indivíduos acima de 50 anos, pode chegar a 68\%. As intervenções cirúrgicas destinadas a corrigir a deformidade da coluna vertebral em pacientes idosos são acompanhadas por um alto risco de complicações. A fusão intersomática lombar por via lateral (LLIF) está associado a uma taxa menor de complicações em comparação com as fusões anteriores ou posteriores abertas. Métodos: Noventa e três pacientes com EDA (23 homens, 70 mulheres) foram operados no Centro Federal de Neurocirurgia. A média de idade foi de 63 anos (52 a 73 anos). Resultados: A dor nas costas, de acordo com a escala visual analógica (EVA) diminuiu de 5,9/6 (4; 8 quartis) (formato média/mediana [1; 3 quartis]) para 2,6/3 (1; 3 quartis) ( $p<0,0001)$. A dor nas pernas, também de acordo com a EVA, diminuiu de 4,6/4 (3; 7 quartis) para 1,4/1 (0; 2 quartis) ( $p<$ 0,0001). A adaptação funcional, de acordo com o Índice de Incapacidade de Oswestry (ODI) melhorou de 47,8 \pm 17,4 para 38,5 \pm 14,5 ( $p<0,0273$ ). A inclinação pélvica (PT) antes da cirurgia era de 23, $9 \pm 12,2^{\circ}$, enquanto nos 12 meses de acompanhamento era de 16,8 \pm 5,9 ( $<$ <,0001). A incompatibilidade pré-cirúrgica de IP-LL foi de 12,1/13 (9; 16), enquanto 12 meses depois foi de -7,9/8 (6; 10) $(p=0,0002)$. Conclusões: A restauração do equilíbrio sagital local em pacientes com EDA por fixação de segmento curto, usando a tecnologia LLIF, proporciona melhora estatisticamente significativa na qualidade de vida e aumenta a adaptação funcional. A menor incidência de complicações pós-operatórias precoces e tardias, a menor perda sanguínea intraoperatória e menor tempo de internação possibilitam que a LLIF, em combinação com a fixação transpedicular minimamente invasiva, seja o método de escolha para corrigir a EDA em pacientes idosos. Nível de evidência IV; Série de casos.

Descritores: Adulto; Escoliose; Coluna; Deformidade; Qualidade de Vida.

\section{RESUMEN}

Objetivo: La incidencia de escoliosis degenerativa del adulto (EDA) entre individuos con más de 50 años puede llegar a 68\%. Las intervenciones quirúrgicas destinadas a corregir la deformidad de la columna vertebral en pacientes del grupo de la tercera edad son acompañadas por un alto riesgo de complicaciones. La fusión intersomática lumbar por vía lateral (LLIF) está asociada a una tasa menor de complicaciones en comparación con las fusiones anteriores o posteriores abiertas. Métodos: Noventa y tres pacientes con EDA (23 hombres, 70 mujeres)

Study conducted at the Federal Neurosurgical Center, Department of Neurosurgery, Novosibirsk, Russia.

Correspondence: Ivan Vasilenko. Nemirovicha-Danchenko str., 132/1, Novosibirsk, Russia.630087. HYPERLINK "mailto:v klimov@neuronsk.ru"i vasilenko@neuronsk.ru 
fueron operados en el Centro Federal de Neurocirugía. El promedio de edad fue de 63 años (52 a 73 años). Resultados: El dolor de espalda, de acuerdo con la escala visual analógica (EVA) disminuyó de 5,9/6 (4; 8 cuartiles) (formato promedio/mediana [1; 3 cuartiles) para 2,6/3 (1; 3 cuartiles) ( $p<0,0001)$. El dolor en las piernas, también de acuerdo con EVA, disminuyó de 4,6/4 (3; 7 cuartiles) para 1,4/1 (0; 2 cuartiles) ( $p<0,0001)$. La adaptación funcional, de acuerdo con el Índice de Incapacidad de Oswestry (ODI) mejoró de 47,8 \pm 17,4 para 38,5 \pm $14,5$ ( $p<0,0273)$. La inclinación pélvica (PT) antes de la cirugía era de 23,9 $912,2^{\circ}$, mientras que en los 12 meses de acompañamiento fue de 16,8 8 5,9 (p <0,0001). La incompatibilidad prequirúrgica de IP-LL fue de 12,1/13 (9; 16), mientras que 12 meses después fue de -7,9/8 (6; 10) ( $p=0,0002)$. Conclusiones: La restauración del equilibrio sagital local en pacientes con EDA por fijación de segmento corto, usando la tecnología LLIF, proporciona mejora estadísticamente significativa en la calidad de vida y aumenta la adaptación funcional. La menor incidencia de complicaciones postoperatorias precoces y tardías, la menor pérdida sanguínea intraoperatoria y un menor tiempo de internación posibilitan que la LLIF, en combinación con la fijación transpedicular mínimamente invasiva, sea el método de elección para corregir la EDA en pacientes de la tercera edad. Nivel de evidencia IV; Series de casos.

Descriptores: Adulto; Escoliosis; Columna vertebral; Deformidad; Calidad de Vida.

\section{INTRODUCTION}

The prevalence of adult degenerative scoliosis (ADS) among people over 50 years of age can be as high as $68 \%$ and is seen to increase further with age..$^{1,2}$ The main pathology in patients with lumbar ADS is degeneration of the intervertebral discs, ${ }^{3}$ which leads to deformity and subsequent spinal imbalance. Studies have shown that patients with ADS who are in positive sagittal balance have increased pain and poor quality of life..$^{4-7}$ Hence, the main goal of the surgical treatment in patients with ADS is to reconstruct the spinal profile. ${ }^{8}$

Operative interventions to correct spinal deformity in the elderly population is associated with a high risk of complications. This is due to the presence of co-morbidities, poor cardio-respiratory reserve and, in part, to the nature of the surgical intervention planned. ${ }^{9-10}$ Therefore, the use of minimally invasive technologies to correct sagittal imbalance may be advantageous in this group of patients.

Lateral lumbar interbody fusion (LLIF) was developed as a technique that allowed correction of deformity in the coronal and sagittal planes, along with indirect decompression of the nerve roots. ${ }^{11-13}$ Studies have shown that LLIF may be associated with fewer complications as compared to open spinal fusion procedures. ${ }^{14-16}$ In spite of this, the literature on the use of LLIF for surgical correction of ADS is scarce. This may be due to the high cost of LLIF, difficulties in accurately assessing sagittal balance, and the presence of neglected forms of multilevel spinal stenosis and instability. ${ }^{15,17}$ Also, there is no unified view on the assessment of clinical and radiologic outcomes in patients with ADS. Due to the aforementioned factors, this study was undertaken to analyze our experience and outcomes in the use of LLIF for the treatment of degenerative scoliosis in adults.

\section{METHODS}

This is a retrospective study of the medical records and imaging examinations of patients who underwent surgical treatment for degenerative lumbar scoliosis. It was conducted following approval by the Ethics Committee (No. 1, dated January 29, 2018). All patients signed an informed consent form before participating in the study. A retrospective review was conducted of 93 patients who underwent surgery for degenerative lumbar scoliosis in a single center (Department of Spinal Surgery; Federal Neurosurgical Centre; Novosibirsk) between 2014 and 2017. Seventy (75\%) of the subjects were women; $23(25 \%)$ were men.

The inclusion criteria for the study were:

- degenerative lumbar scoliosis with a coronal plane Cobb angle $>10^{\circ}$;

- clinical manifestations of vertebral pain syndrome, radiculopathy and/or their combination;

- failure to respond to conservative treatment for at least two months.

Patients with idiopathic scoliosis or who had undergone previous spinal surgery were excluded from the study.

Pre and post-operative neurological examinations were recorded, and a detailed neurological examination was performed 24 months after surgery.
Standing lumbosacral spine $\mathrm{X}$-ray (including the head of femur) in two projections, computed tomography (CT) and magnetic resonance imaging (MRI) of the lumbar spine were also assessed. To assess the severity of back pain and leg pain, the visual analogue scale (VAS) for pain was used. The degree of functional adaptation was assessed using the Oswestry Disability Index (ODI) questionnaire. ${ }^{18}$ Quality of life was evaluated using the Short Form-36 (SF36) questionnaire, focusing on the components physical health $(\mathrm{PH})$ and mental health $(\mathrm{MH}) .{ }^{19}$

\section{Surgical technique.}

The patient was positioned on the lateral side. The operating table was angled under the concave vertebral deformity in the region of surgical interest. An incision was made obliquely at the side of the waist, projecting towards intervertebral discs of deformed segment. Next, the external, internal oblique and transversus muscles were separated, and the iliopsoas muscle was separated. All patients underwent neurophysiological monitoring during surgery, for spontaneous electromyographic activity in the rectus femoris/vastus lateralis (L2-L4) and tibialis anterior/gastrocnemius (L5-S1) muscles at the side of the surgery. Electrical stimulation of the nerve roots and lumbar plexus branches innervating the leg muscles was also performed intraoperatively. The discs were removed and endplate curettage performed. The space between the bony vertebrae was filled with a cage (Oracle) and osteoinductive materials (ChronOs and i-factor). Patient was then turned so that they were prone, and percutaneous transpedicular screws were inserted. All patients received routine perioperative antibiotic cover.

The sagittal balance parameters were determined using the software program Sagittal Balance Academy (www.sagittal-balance. com). Spinal deformity was classified according to the SRS-Schwab criteria, using classification modifiers to assess sagittal and coronal balance: ${ }^{20}$ the type of arc in the coronal plane $(T, T L, L, N)$; sagittal modifiers PI (pelvic incidence), SS (sacral slope), PT (pelvic tilt), and $\mathrm{LL}$ (lumbar lordosis). The target values of the integrated SVA (sagittal vertical axis) and PI-LL (PI minus LL) parameters were determined and adjusted for age. ${ }^{20}$ To determine the target LL parameter, we used the formula $L L=\mathrm{PI} \times 0.5+28^{\circ} .{ }^{21}$

The criteria proposed by White and Panjabi were used for the diagnosis of instability. ${ }^{22}$

The duration of surgery, amount of blood loss and duration of hospital stay were also recorded.

During follow-up, the degree of bone block formation was estimated according to the Bridwell scale, ${ }^{23}$ and the degree of transpedicular screws malposition was assessed according to the Rao classification (2003). ${ }^{24}$

Statistical data analysis. A two-sided Wilcoxon test was used to compare the dependent samples. The level of statistical significance in the study was assumed to be 0.05 . The format mean/median $(1 ; 3$ quartile) was used for data outside the normal distribution (Shapiro-Wilk test), otherwise the mean \pm 2 standard deviation was used. The calculations were carried out using the software program $R$, version 3.4.3. ${ }^{25}$ 


\section{RESULTS}

The mean age of the patients was 63 years (52 to 73 years). Vertebrogenic pain syndrome was the main clinical manifestation in all the patients. Sixty-four (76\%) patients had a combination of vertebrogenic pain syndrome and radiculopathy. Of these 64 patients, $56(87.5 \%)$ had $L 4$ radiculopathy, and the remaining $8(12.5 \%)$ had L3 radiculopathy. Radicular pain was attributed to compression of the corresponding nerve root in the foramen on the concave side of the deformity, which was confirmed by the radiological data.

Assessing the type of deformity according to the classification of SRS-Schwab, the coronal plane modifier corresponded to type $\mathrm{N}$ (less than $30^{\circ}$ ) in all patients. The parameters for sagittal balance prior to surgery are shown in Figure 1.

The sagittal modifier PI-LL "0" was detected in 40 (48\%) patients, the PI-LL "+ " modifier was seen in 25 (29\%) patients, and the PI-LL "++" modifier in 19 (23\%) patients.

The sagittal modifier SVA "0" was seen in 56 (67\%) patients, SVA "+ " in 18 (21\%) patients and SVA "++" in 10 (12\%) patients.

The sagittal modifier PT "0" was seen in 31 (37\%) patients, PT "+ " in 34 (40\%) patients and PT "++" in 19 (23\%) patients.

The local lumbar sagittal imbalance was seen in $75 \%$ of cases (63 patients) whereas the remaining $25 \%$ of cases (21 patients) had a combination of local and global sagittal imbalance; the SVA value for them was $120 \pm 43 \mathrm{~mm}$.

Preoperative radiology and clinical examination did not reveal evidence of instability in any of the patients; the value was $3 \pm 1$ points i.e., below 5 points according to White \& Panjabi.

Interbody fusion was carried out at one level in $6(7 \%)$ patients, at two levels in 48 (57\%) patients and at 3 levels in $30(36 \%)$ patients.

The blood loss was $226.3 \pm 112 \mathrm{ml}$. The operative time was $240 \pm 80 \mathrm{~min}$, and the hospital stay was $7 \pm 3$ days

In a single-level interbody fusion PI and LL before surgery were $62 \pm 15^{\circ}$ and $51 \pm 9^{\circ}$ respectively. Postoperatively LL was $64 \pm 7^{\circ}$, which changes were statistically significant $(p=0.0002)$. In patients who underwent two-level interbody fusion, the mean PI and LL presurgery were $55 \pm 7^{\circ}$ and $44 \pm 9^{\circ}$ respectively. In the postoperative period $\mathrm{LL}$ was $60 \pm 6^{\circ}(\mathrm{p}=0.0273)$. Whereas in patients who underwent a three-level interbody fusion, PI and LL before surgery were $60 \pm 7^{\circ}$ and $45 \pm 10^{\circ}$ respectively. In the postoperative period, a statistically significant change in $\mathrm{LL}$ to $62 \pm 8^{\circ}$ was seen $(p=0.0008)$. Dynamics of the preoperative parameters and at 12 months follow-up are presented in Table 1.

In 63 (75\%) out of the 84 patients with local sagittal imbalance, the SVA did not exceed $40 \mathrm{~mm}$. Whereas in the remaining $21(25 \%)$ patients with both local and global sagittal imbalance, the SVA varied between $84 \mathrm{~mm}$ and $183 \mathrm{~mm}$ (SVA value of $120 \pm 43$ $\mathrm{mm})$. Statistically significant improvement in the parameters of local sagittal balance was seen after the surgery [PT ( $p<0.0001), \mathrm{PI}-\mathrm{LL}$ $(p=0.0002)]$. In patients with impaired global sagittal balance, a decrease in the SVA to $22 \pm 10 \mathrm{~mm}$ was noted.

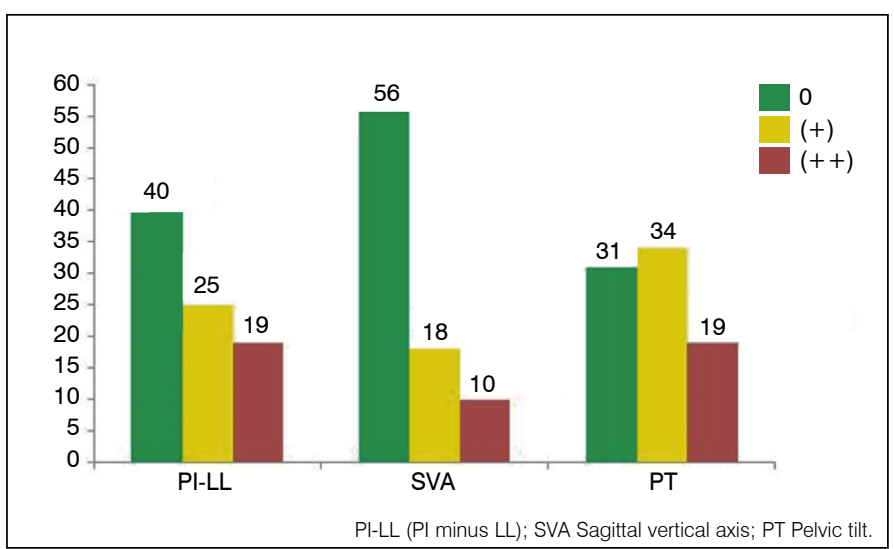

Figure 1. Parameters of the sagittal balance before the operation.

\section{Clinical case}

Patient D, 60 years old with degenerative scoliosis of $20^{\circ}$ Cobb (b) and severe back pain to 8 points on VAS and left leg of 6 points on VAS, which was associated with compression of the $L 4$ spine root at the level of the intervertebral foramen on the concave side of the deformation. PI was noted to be $55^{\circ}$ (a). The lumbar lordosis was sharply lowered to $20^{\circ}$ as compared to the expected value of $55^{\circ}$ $\left(\mathrm{LL}=\mathrm{PI} \times 0.5+28^{\circ}\right)$. Also, we saw a compensatory retroversion of

Table 1. Dynamics of parameters before the operation and at 12 months follow-up and the level of statistical significance (p).

\begin{tabular}{c|c|c|c}
\hline Parameters & Value before operation & Value after operation & $\mathbf{P}$ \\
\hline VAS back & $5.9 / 6(4 ; 8)$ & $2.6 / 3(1 ; 3)$ & $<0.0001$ \\
\hline VAS leg & $4.6 / 4(3 ; 7)$ & $1.4 / 1(0 ; 2)$ & $<0.0001$ \\
\hline PT & $23.9 \pm 12.2^{\circ}$ & $16.8 \pm 5.9^{\circ}$ & $<0.0001$ \\
\hline PI-LL & $12.1 / 13(9 ; 16)^{\circ}$ & $7.9 / 8(6 ; 10)^{\circ}$ & 0.0002 \\
\hline Cobb Angle & $28 \pm 3.5^{\circ}$ & $9.2 \pm 2.3$ & $<0.0001$ \\
\hline ODI & $47.8 \pm 17.4$ & $38.5 \pm 14.5$ & 0.0273 \\
\hline SF36 PH & $27.9 / 28.9(24.6 ; 29.4)$ & $35.4 / 36.1(31.2 ; 40.4)$ & 0.0005 \\
\hline SF36 MH & $32.3 / 28(23.6 ; 38.1)$ & $40.1 / 37.6(33.4 ; 47.6)$ & 0.0056 \\
\hline
\end{tabular}

SVA-Sagittal vertical axis; PT-Pelvic tilt; PI-Pelvic incidence; LL-lumbar lordosis; ODI-Oswestry Disability Index; SF36-Short Form-36.

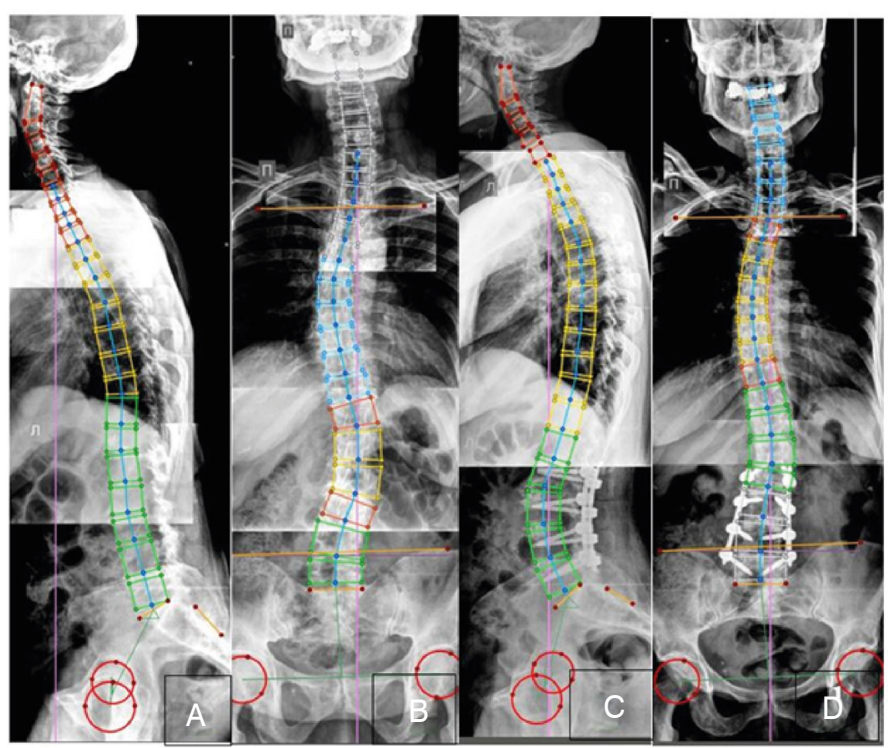

Figure 2. X-ray in the frontal and sagittal planes before (A, B) and after (C, D) surgery.

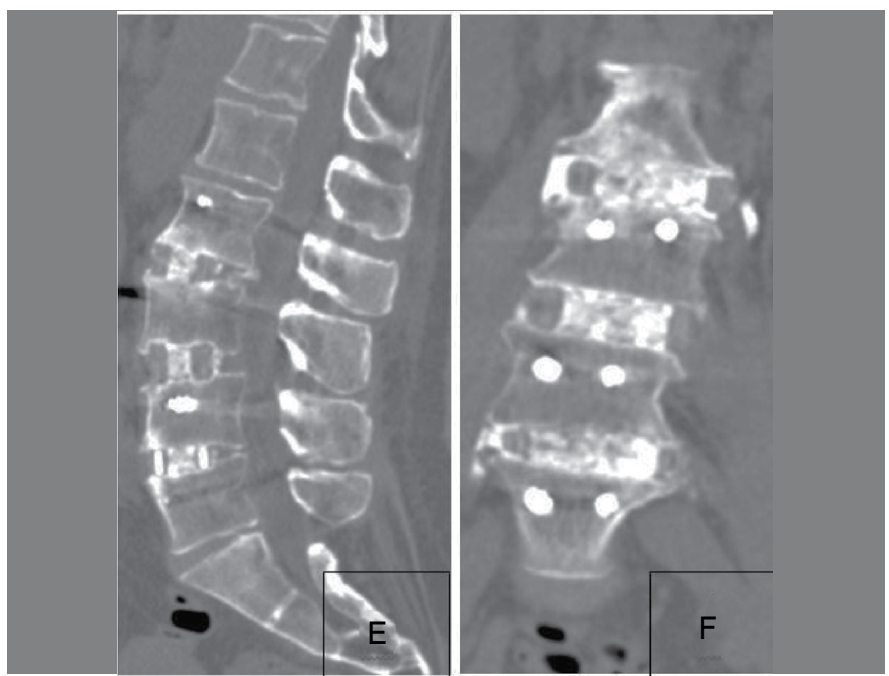

Figure 3. $C T$ in the frontal and sagittal planes (E, F), follow up 12 months. 
the pelvis $\left(\mathrm{PT}=28^{\circ}\right.$ ), and a gross violation of both the local lumbar and global sagittal body balance SVA $=134 \mathrm{~mm}$ (a).

We chose a minimally invasive treatment: three-level LLIF and percutaneous transpedicular fixation L2-L5 (c, d). The operation time was 4 hours and total blood loss was $270 \mathrm{ml}$. There were no intraoperative complications. Post-operatively, the scoliosis was decreased to $4^{\circ}$ Cobb (d). Short fusion correction of local lordosis $\left(\mathrm{LL}=57^{\circ}\right.$ ) led to restoration of the global sagittal body balance (PT $=15^{\circ}$, SVA equals $41 \mathrm{~mm}$ ) (c). Improvement in clinical symptoms in the early postoperative period was also noted. Thus, correcting only the local sagittal balance provided correction of deformation in the frontal plane, along with indirect decompression of $L 4$.

CT of the lumbosacral spine $(e, f)$ at 12 months after surgery was used to determine the bone block formation at the implanted level.

Complications were divided into neurological, implant-related and general.

In the early postoperative period, 5 (5.9\%) patients experienced transient weakness of the hip flexor muscles on the ipsilateral side of the surgery, which was thought to be due to direct trauma to the large lumbar muscles. In 8 (9.5\%) patients there was a decrease in pain and temperature sensitivity on the anterior surface of the thigh on the ipsilateral side of the surgery, which was caused by irritation of the genitofemoral and lateral cutaneous nerve. In 7 of these cases, these symptoms resolved within 6 months of surgery whereas in 1 patient, it persisted

A total of 396 pedicle screws were inserted, $2(0.5 \%)$ of which had a medial breach on CT scan (1st degree of Rao). As patients remained asymptomatic, none of these required revision surgery. In $7(1.76 \%)$ screws, damage to the cortex was seen on CT.

At 24 months follow-up, pseudoarthrosis was seen at 2 (1.04\%) (Grade 4 by Bridwell) levels out of a total of 192 levels fused, both of which required revision surgery.

Two patients (2.3\%) developed adjacent level disease and required revision surgery. Two (2.3\%) patients presented wound haematoma but none of them required evacuation. Two (2.3\%) patients developed paresis of the anterior abdominal wall muscles on the access side, which was thought to be due to traction on iliohypogastric nerve. Both these patients required abdominal binder in the immediate post-operative period. There was no case of wound infection.

\section{DISCUSSION}

The main goal of surgical treatment in patients with ADS is to restore the balance of spine in the sagittal and coronal planes in order to reduce pain and improve quality of life and functional status. ${ }^{26,27}$ The use of standard open methods of surgical correction of ADS is associated with extensive muscle dissection, high blood loss, and prolonged hospital stay. ${ }^{28-30}$ Standard open methods of surgical correction of ADS may also be associated with a higher incidence of infection, failure of the fixation, and junctional kyphosis, which can lead to a poor outcome. ${ }^{31,32}$ In recent years, minimally invasive surgery in combination with short-segment fixation of the spine has been used for the treatment of this group of patients ${ }^{33-36}$ (Table 2). Clinical and radiological outcomes of minimally invasive and open surgery have shown similar results.

\section{Clinical outcomes depending on sagittal balance parameters}

According to several authors, target indices for spine and pelvic interactions in the treatment of patients with ADS are: SVA, PT, PI-LL, and Cobb angle in the coronal plane. ${ }^{37-39}$ Schwab et al., showed that during deformity correction in the sagittal plane, it is necessary to aim for SVA $<40 \mathrm{~mm}$ and PT $<20^{\circ}$ with appropriate correction for age. ${ }^{40} \mathrm{PI}-\mathrm{LL} \leq 10^{\circ}$ is recommended in this category of patients, and this has been shown to significantly improve the quality of life in the postoperative period. ${ }^{40}$

However, other authors, such as Le Huec, Lamartina and Roussouly, have shown that the key to improving the quality of life in patients with ADS is to restore the segmental lumbar lordosis. In their opinion, the spino-sacral angle (SSA) is preferable to the SVA in assessing the global sagittal balance. ${ }^{41}$ The authors felt that compensatory mechanisms such as pelvic deflection, pelvic incline, flexion at the hip and knee joints are not taken into account when SVA is used to assess global sagittal balance. In order to ensure a normal SSA of 134 $\pm 8^{\circ}$ the authors recommend restoration of the local sagittal balance of the lumbar spine, particularly of the L4-S1 segment, which accounts for almost $70 \%$ of the SSA. The calculation of the LL index should be based on $\mathrm{PI}$ and calculated by the formula $\mathrm{LL}=\mathrm{PI} \times 0.5+28^{\circ}$.

In our study, we also noted a statistically significant reduction in VAS for back $(p=0.0001)$ and leg $(p=0.0002)$ pain. The average volume of blood loss was $226.3 \pm 112 \mathrm{ml}$, with an average operating time of $240 \pm 80$ min and average hospital stay of $7 \pm 3$ days.

There was also a statistically significant improvement in the quality of life indicators and degree of functional adaptation.

\section{Clinical outcomes depending on the correction of deformation}

Since ADS surgery involves correction in the sagittal and coronal planes, we decided to evaluate the degree of correction obtained with various surgical approaches.

The analysis of available literature data and the results of our study suggest that deformity correction by standard open surgery via a posterior approach (Table $3^{28,29,30}$ ) and LLIF in combination with MIS transpedicular screws (Table $3^{14,17,36,42}$ ) provided similar correction in terms of LL, PT, PI-LL and Cobb angle.

\section{Clinical outcomes depending on surgical technique}

The choice of surgical technique in patients with ADS, especially in the older age group, should represent a reasonable compromise between the planned surgical intervention and the associated operative risks. This is due to a higher incidence of comorbidities, the presence of osteoporosis and the higher body mass index in this group of patients. Consequently, the use of minimally invasive techniques in this category of patients reduces blood loss, risks of complications, and length of hospital stay.

Several studies recommend the use of different variants of osteotomy in standard surgical techniques for correction of degenerative scoliotic deformity. However, these are associated with prolonged operative times, high blood loss, longer hospital stay, and a significant risk of complications, both during surgery and in the postoperative period, as well as longer recovery and rehabilitation periods, Table $4 .{ }^{26,28-30,43-46}$

The use of LLIF technology in the surgical treatment of ADS is accompanied by greatly reduced intraoperative blood loss.

Table 2. Study characteristics of included studies on short fusion or long fusion for adult degenerative scoliosis.

\begin{tabular}{|c|c|c|c|c|c|c|c|}
\hline & \begin{tabular}{|c|} 
Total \\
No. Of patients
\end{tabular} & Surgery & Operation time $(\mathrm{min})$ & Blood loss (ml) & $\begin{array}{c}\text { Hospital stay } \\
\text { (days) }\end{array}$ & ODI befo op & ODI post op (P value) \\
\hline Zhang et al. ${ }^{30}$ & \begin{tabular}{|c|}
44 \\
\end{tabular} & open & $284.5 \pm 30.2$ & $1040.5 \pm 1207.6$ & $14.5 \pm 1.9$ & & $17.3 \pm 4.9(P<0.001)$ \\
\hline Sun et al. ${ }^{29}$ & 74 & open & $237.8 \pm 39.7$ & $1017.2 \pm 813.3$ & $14.5 \pm 1.3$ & & $18.4 \pm 5.8(P<0.001)$ \\
\hline Simon et al. ${ }^{28}$ & 47 & open & $284.5 \pm 30.2$ & $1040.5 \pm 1207.6$ & $14.5 \pm 1.9$ & & 33.61 \\
\hline Lee et al. ${ }^{36}$ & 168 & LLIF & & & & & \\
\hline Anand et al. ${ }^{33}$ & 28 & LLIF + TPF & & 241 & & 53.5 & 25.9 \\
\hline Diaz et al. ${ }^{34}$ & 39 & LLIF & 125 & 50 & & 49 & 23 \\
\hline Konovalov et al. ${ }^{35}$ & 36 & LLIF & & $163.9 \pm 50$ & & $73.45 \pm 4.2$ & $22.89 \pm 2.24 .(p<0.05)$ \\
\hline
\end{tabular}


Table 3. Summary of coronal Cobb angle, PI-LL (PIminusLL) and SVA preoperatively, and postoperatively. (PI-LL, Pelvic incidence minus Lumbar Lordosis; SVA, Sagittal vertical axis).

\begin{tabular}{|c|c|c|c|c|c|c|}
\hline & $\begin{array}{c}\text { Cobb angle pre op } \\
\left({ }^{\circ}\right)\end{array}$ & $\begin{array}{c}\text { Cobb angle post op } \\
\left({ }^{\circ}\right)\end{array}$ & $\begin{array}{c}\text { PI-LL pre op } \\
\left({ }^{\circ}\right)\end{array}$ & $\begin{array}{c}\text { PI-LL post op }\left({ }^{\circ}\right) \\
\text { P value } \\
\end{array}$ & $\begin{array}{c}\text { SVA pre op } \\
(\mathrm{mm})\end{array}$ & $\begin{array}{c}\text { SVA post op }(\mathrm{mm}) \\
\text { P value }\end{array}$ \\
\hline Sun et al. ${ }^{29}$ & $20.3 \pm 2.8^{\circ}$ & $4.2 \pm 1.8^{\circ}$ & $36.0 \pm 4.4^{\circ}$ & $16.6 \pm 8,7^{\circ}(p<0.05)$ & & \\
\hline Lee et al. ${ }^{36}$ & & & $29.6 \pm 19.3^{\circ}$ & $15.9 \pm 14.8^{\circ}(p=0.012)$ & $74.8 \pm 38.2$ & $31.7 \pm 17.2(p 0.000)$ \\
\hline Tormenti et al. ${ }^{17}$ & $38.5^{\circ}$ & $10^{\circ}(p<0.0001)$ & & & & \\
\hline Justin S. Smith et al. ${ }^{42}$ & от $43^{\circ}$ до $54^{\circ}$ & & от $26^{\circ}$ до $20^{\circ}$ & от $6^{\circ}$ до $5^{\circ}(p<0.001)$ & From 12 to 1.7 & $-1,1$ см до $+4,8(p \leq 0.009)$ \\
\hline
\end{tabular}

PI-LL - PI minus LL; SVA - Sagittal vertical axis.

Table 4. Complications of short fusion and long fusion surgery for adult degenerative scoliosis.

\begin{tabular}{|c|c|c|c|c|c|}
\hline & \begin{tabular}{|c|} 
Total \\
No. of \\
patients
\end{tabular} & $\begin{array}{c}\text { General } \\
\text { complications }\end{array}$ & $\begin{array}{c}\text { Infectious } \\
\text { complications }\end{array}$ & $\begin{array}{c}\text { Neurological } \\
\text { complications }\end{array}$ & $\begin{array}{l}\text { Mechanical } \\
\text { complications }\end{array}$ \\
\hline $\begin{array}{l}\text { Zhang } \\
\text { et al. }\end{array}$ & 44 & & & & $9 \%$ \\
\hline $\begin{array}{l}\text { Sun } \\
\text { et al. }^{29}\end{array}$ & 74 & & $33.4 \%$ & & $29.4 \%$ \\
\hline $\begin{array}{l}\text { Simon } \\
\text { et al. }^{28} \\
\end{array}$ & 47 & & $12,8 \%$ & $6.4 \%$ & $19.1 \%$ \\
\hline $\begin{array}{c}\text { Charosky } \\
\text { et al. }{ }^{26} \\
\end{array}$ & 306 & $13.7 \%$ & $5.2 \%$ & $7.5 \%$ & $23.8 \%$ \\
\hline $\begin{array}{l}\text { Daubs } \\
\text { et al. }{ }^{43}\end{array}$ & 46 & $37 \%$ & $4.3 \%$ & $8.6 \%$ & \\
\hline $\begin{array}{l}\text { Yadla } \\
\text { et al. }^{46}\end{array}$ & 2129 & $41.2 \%$ & & & $12.9 \%$ \\
\hline $\begin{array}{l}\text { Kotwal } \\
\text { et al. }{ }^{14}\end{array}$ & 118 & $9.3 \%$ & & $0.8 \%$ & $11.8 \%$ \\
\hline $\begin{array}{l}\text { Smith } \\
\text { et al. }{ }^{45}\end{array}$ & 578 & $24.5 \%$ & $7.0 \%$ & $6.1 \%$ & $3.4 \%$ \\
\hline $\begin{array}{l}\begin{array}{l}\text { Tohmeh } \\
\text { et al. }{ }^{16}\end{array} \\
\end{array}$ & 102 & $1.9 \%$ & & $6.8 \%$ & \\
\hline $\begin{array}{c}\text { Pumberger } \\
\text { et al. }{ }^{15}\end{array}$ & 235 & & & $3.7 \%$ & \\
\hline $\begin{array}{l}\text { Kim } \\
\text { et al. }{ }^{44}\end{array}$ & 233 & & $11.5 \%$ & $4.5 \%$ & $19.1 \%$ \\
\hline
\end{tabular}

When using the LLIF technique in adult deformity surgery, the concept of minimally invasive surgery is used: skin incision is smaller and there is less soft tissue trauma, smaller bone defect, lack of contact with dura mater and reduced retractive soft tissue injuries which significantly decreases the rate of wound infection, volume of blood loss and duration of hospital stay. The interbody implant used has a large contact area in comparison with other implants and is based on the dense part of the end plate, thereby creating greater support for the anterior column while maintaining middle and posterior column support to the spine. Lateral interbody fusion does not require resection of bony structures as indirect decompression of nerve root is performed without opening the spinal canal as the height of the interbody cage restores the size of the intervertebral foramen. With LLIF technique, anterior and posterior longitudinal ligaments are preserved which prevents the migration of the interbody implant and increases the dynamic stability due to ligamentotaxis. However, the application of this technique has its specific complications, Table $4^{14-16}$

According to the authors, ${ }^{14-15}$ weakness of hip flexor muscles was due to direct trauma to the lumbar muscles during access to the lateral spine and traction of the muscles during the operation, rather than trauma to the lumbar plexus.

According to our data, 11 (13\%) patients had neurological complications of which $3.5 \%$ of complications were persistent. The standard use of LLIF technology makes it possible to completely exclude the contact with dura mater and consequently the chances of its damage during the surgery.

\section{CONCLUSION}

Use of LLIF in patients with ADS ( $\mathrm{N} \leq 30^{\circ}$ according to SRSSchwab) provides adequate surgical correction of the spinal deformity both in the sagittal and coronal planes. Restoration of local sagittal balance in this category of patients by short-segment fixation using LLIF technology led to a statistically significant improvement in quality of life and an increase in patients' functional adaptation.

Due to the significantly lower incidence of early and late postoperative complications, less intraoperative blood loss, and shorter hospital stay, LLIF in combination with MIS transpedicular fixation is the method of choice for correction of ADS in elderly patients.

All authors declare no potential conflict of interest related to this article.

CONTRIBUTION OF THE AUTHORS: Each author made significant individual contributions to this manuscript. VSK and IIV were the main contributors to the writing of the manuscript, and performed the surgeries. JAR reviewed the manuscript, AVE performed the surgeries, RVK performed the surgeries, EVA conducted the statistical analysis, SOR reviewed the manuscript, PS reviewed the manuscript, and MI reviewed the manuscript.

\section{REFERENCES}

1. Kobayashi T, Atsuta Y, Takemitsu M, Matsuno T, Takeda N. A prospective study of de novo scoliosis in a community based cohort. Spine (Phila Pa 1976). 2006;31(2):178-82.

2. Schwab F. Dubey A, Gamez L, El Fegoun AB, Hwang K, Pagala M, et al. Adult scoliosis: prevalence, SF-36, and nutritional parameters in an elderly volunteer population. Spine (Phila Pa 1976). 2005;30(9):1082-5.

3. Aebi M. The adult scoliosis. Eur Spine J. 2005:14:925-48.

4. Glassman SD, Bridwell K, Dimar JR, Horton W, Berven S, Schwab F. The impact of positive sagittal balance in adult spinal deformity. Spine (Phila Pa 1976). 2005;30(18):2024-9.

5. Liu S, Schwab F, Smith JS, Klineberg E, Ames CP, Mundis G, et al. Likelihood of reaching minimal clinically important difference in adult spinal deformity: a comparison of operative and nonoperative treatment. Ochsner J. 2014;14(1):67-77.

6. Mac-Thiong JM, Roussouly P, Berthonnaud E, Guigui P. Sagittal parameters of global spinal balance: normative values from a prospective cohort of seven hundred nine Caucasian asymptomatic adults. Spine (Phila Pa 1976). 2010;35(22):E1193-8.
7. Zheng X, Chaudhari R, Wu C, Mehbod AA, Transfeldt EE, Winter RB. Repeatability test of C7 plumb line and gravity line on asymptomatic volunteers using an optical measurement technique. Spine (Phila Pa 1976). 2010:35(18):E889-94.

8. Berjano P, Lamartina C. Far lateral approaches (XLIF) in adult scoliosis. Eur Spine J. 2006;22 (Suppl 2):S242-53.

9. DeWald CJ, Stanley T. Instrumentation-related complications of multilevel fusions for adult spinal deformity patients over age 65: surgical considerations and treatment options in patients with poor bone quality. Spine (Phila Pa 1976). 2006:31(19 Suppl):S144-51.

10. Schwab F, Lafage V. Farcy JP. Bridwell KH, Glassman S. Shainline MR. Predicting outcome and complications in the surgical treatment of adult scoliosis. Spine (Phila Pa 1976). 2008;33(20):2243-7.

11. Acosta FL, Liu J, Slimack N, Moller D, Fessler R, Koski T. Changes in coronal and sagittal plane alignment following minimally invasive direct lateral interbody fusion for the treatment of degenerative lumbar disease in adults: a radiographic study. J Neurosurg Spine. 2011;15(1):92-6. 
12. Ozgur BM, Aryan HE, Pimenta L, Taylor WR. (2006) Extreme Lateral Interbody Fusion (XLIF): a novel surgical technique for anterior lumbar interbody fusion. Spine J. 2006:6(4):435-43.

13. Pimenta L, Vigna F, Bellera F, Schaffa T, Malcolm J, McAfee A. New minimally invasive surgical technique for adult lumbar degenerative scoliosis. Proceedings of the 11th International Meeting on Advanced Spine Techniques (IMAST), Southampton, Bermuda. 2004.

14. Kotwal S, Kawaguchi S, Lebl D, Hughes A, Huang R, Sama A, et al. Invasive Lateral Lumbar Interbody Fusion Clinical and Radiographic Outcome at a Minimum 2-year Follow-up. J Spinal Disord Tech. 2015;28(4):119-25.

15. Pumberger M, Hughes AP, Huang RR, Sama AA, Cammisa FP, Girardi FP. Neurologic deficit following lateral lumbar interbody fusion. Eur Spine J. 2012;21 (6):1192-9.

16. Tohmeh AG, Rodgers WB, Peterson MD. Dynamically evoked, discrete-threshold electromyography in the extreme lateral interbody fusion approach. J Neurosurg Spine. 2011:14(1):31-7.

17. Tormenti MJ, Maserati MB, Bonfield CM, Okonkwo DO, Kanter AS. Complications and radiographic correction in adult scoliosis following combined transpsoas extreme lateral interbody fusion and posterior pedicle screw instrumentation. Neurosurg Focus. 2010;28(3):E7

18. Fairbank JCT, Pynsent PB. The Oswestry Disability Index. Spine (Phila Pa 1976). 2000:25(22):2940-53

19. Ware JE, Kosinski M, Keller SD. SF-36 Physical and Mental Health Summary Scales: A User's Manual. The Health Institute, New England Medical Center. Boston, Mass. 1994;823-8.

20. Schwab F, Lafage R, Liabaud B, Diebo B, Smith J, Hostin R, et al. Does One Size Fit All? Defining Spinopelvic Alignment Thresholds Based on Age. Spine J. 2014;14(11):S120-1.

21. Le Huec JC, Hasegawa K. Normative values for the spine shape parameters using 3D standing analysis from a database of 268 asymptomatic Caucasian and Japanese subjects. Eur Spine J. 2016;25(11):3630-7.

22. White AA, Panjabi MM. Clinical Biomechanics of the Spine. Philadelphia: Lippincott Williams \& Wilkins: 1978

23. Bridwell KH, Lenke LG, McEnery KW, Baldus C, Blanke K. Anterior fresh frozen structural allografts in the thoracic and lumbar spine. Do they work if combined with posterior fusion and instrumentation in adult patients with kyphosis or anterior column defects? Spine (Phila Pa 1976) 1995:20(12):1410-8

24. Rao G, Brodke DS, Rondina M, Bacchus K, Dailey AT. Inter- and intraobserver reliability of computed tomography in assessment of thoracic pedicle screw placement. Spine (Phila Pa 1976). 2003;28(22):2527-30.

25. A language and environment for statistical computing. R Foundation for Statistical Computing, Vienna, Austria. Available in: https://www.R-project.org. 2020.

26. Charosky S, Guigui P, Blamoutier A, Roussouly P, Chopin D. Complications and risk factors of primary adult scoliosis surgery: a multicenter study of 306 patients. Spine (Phila Pa 1976). 2012;37(8):693-700

27. Lafage V, Schwab F, Patel A, Hawkinson N, Farcy JP. Pelvic tilt and truncal inclination: two key radiographic parameters in the setting of adults with spinal deformity. Spine (Phila Pa 1976). 2009:34:E599-606.

28. Simon J, Longis PM, Passuti N. Correlation between radiographic parameters and functional scores in degenerative lumbar and thoracolumbar scoliosis. Orthop Traumatol Surg Res. 2017;103(2):285-90.

29. Sun XY, Zhang XN, Hai Y. (2017) Optimum pelvic incidence minus lumbar lordosis value after operation for patients with adult degenerative scoliosis. Spine J. 2017;17(7):983-9.
30. Zhang HC, Zhang ZF, Wang ZH, Cheng JY, Wu YC, Fan YM, et al. Optimal Pelvic Incidence Minus Lumbar Lordosis Mismatch after Long Posterior Instrumentation and Fusion for Adult Degenerative Scoliosis. Orthop Surg. 2017;9(3):304-10.

31. Hyun SJ, Lee BH, Park JH, Kim KJ, Jahng TA, Kim HJ. Proximal Junctional Kyphosis and Proximal Junctional Failure Following Adult Spinal Deformity Surgery. Korean J Spine. 2017;14(4):126-32.

32. Smith JS, Shaffrey Cl, Klineberg E, Lafage V, Schwab F, Lafage R, et al. (2017) Complication rates associated with 3-column osteotomy in 82 adult spinal deformity patients: retrospective review of a prospectively collected multicenter consecutive series with 2-year follow-up. J Neurosurg Spine. 2017;27(4):444-57.

33. Anand N, Rosemann R, Khalsa B, Baron EM. Mid-term to long-term clinical and functional outcomes of minimally invasive correction and fusion for adults with scoliosis. Neurosurg Focus. 2010;28(3):E6.

34. Diaz R, Phillips F, Pimenta L, Guerrero L. XLIF for lumbar degenerative scoliosis: outcomes of minimally invasive surgical treatment out to 3 years postoperatively. Spine J. 2006;6(5):75S

35. Konovalov NA, Nazarenko AG, Krut'ko AV, Glukhikh DL, Durni P, Duris M, et al. [Results of surgical treatment for lumbar spine segmental instability]. Zhurnal voprosy neiDrokhirurgii imeni N. N. Burdenko. 2017;81(6):69-80.

36. Lee BH, Yang JH, Kim HS, Suk KS, Lee HM, Park JO, et al. 2017) Effect of Sagittal Balance on Risk of Falling after Lateral Lumbar Interbody Fusion Surgery Combined with Posterior Surgery. Yonsei Med J. 2017;58(6):1177-85.

37. Schwab F, Farcy JP, Bridwell K, Berven S, Glassman S, Harrast J, et al. A clinical impact classification of scoliosis in the adult. Spine (Phila Pa 1976). 2006;31(18):2109-14.

38. Schwab F, Lafage V, Farcy JP, Bridwell K, Glassman S, Ondra S, et al. Surgical rates and operative outcome analysis in thoracolumbar and lumbar major adult scoliosis: application of the new adult deformity classification. Spine (Phila Pa 1976). 2007;32(24):2723-30.

39. Schwab F, Smith VA, Biserni M, Gamez L, Farcy JP, Pagala M. Adult scoliosis: a quantitative radiographic and clinical analysis. Spine (Phila Pa 1976). 2002;27(4):387-92

40. Schwab F, Bess S, Blondel B, Hostin R, Shaffrey C, Smith J, et al. Combined assessment of pelvic tilt, pelvic incidence/lumbar lordosis mismatch and sagittal vertical axis predicts disability in adult spinal deformity: a prospective analysis. Spine J. 2011;11:S158-9.

41. Roussouly P, Gollogly S, Noseda O, Berthonnaud E, Dimnet J. The vertical projection of the sum of the ground reactive forces of a standing patient is not the same as the C7 plumb line: a radiographic study of the sagittal alignment of 153 asymptomatic volunteers. Spine (Phila Pa 1976). 2006;31(11):E320-5.

42. Smith JS, Singh M, Klineberg E, Shaffrey Cl, Lafage V, Schwab FJ, et al. (2014) Surgical treatment of pathological loss of lumbar lordosis (flatback) in patients with normal sagittal vertical axis achieves similar clinical improvement as surgical treatment of elevated sagittal vertical axis. J Neurosurg Spine. 2014;21:160-70.

43. Daubs MD, Lenke LG, Cheh G. Stobbs G, Bridwell KH. (2007) Adult spinal deformity surgery: complications and outcomes in patients over age 60. Spine (Phila Pa 1976). 2007:32(20):2238-44.

44. Kim SS, Cho BC, Kim JH, Lim DJ, Park JY, Lee BJ, et al. Complications of posterior vertebral resection for spinal deformity. Asian Spine J. 2012;6(4):257-65.

45. Smith JS, Sansur CA, Donaldson WF 3rd, Perra JH, Mudiyam R, Choma TJ, et al. Short-term Morbidity and Mortality Associated With Correction of Thoracolumbar Fixed Sagittal Plane Deformity. Spine (Phila Pa 1976). 2011;36(12):958-64

46. Yadla S, Maltenfort MG, Ratliff JK, Harrop JS. Adult scoliosis surgery outcomes: a systematic review. Neurosurg Focus. 2010;28(3):E3. 